\title{
Mobile with an agency: Negotiating the spatiotemporalities of the temp migrant worker
}

\section{Kristina Zampoukos ${ }^{\mathrm{a},}$}

kristina.zampoukos@miun.se

Hege Merete Knutsen

hegemk@sosgeo.uio.no

Maiken Bjerga K

m.b.kiil@sosgeo.uio.no

Gunilla Olofsdotter

gunilla.olofsdotter@miun.se

aMid-Sweden University, Department of Tourism Studies and Geography, Kunskapens väg 1, 83125 Östersund, Sweden

${ }^{\mathbf{b}}$ Department of Sociology and Human Geography, University of Oslo, P.O. Box 1096 Blindern, 0317 Oslo, Norway

${ }^{c}$ Mid-Sweden University, Department of Social Sciences, Holmgatan 10, 85170 Sundsvall, Sweden

${ }^{*}$ Corresponding author.

Abstract

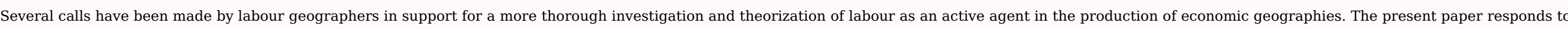

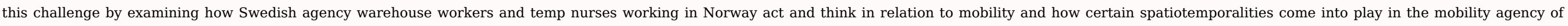

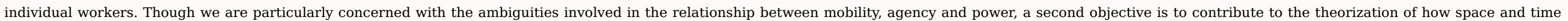

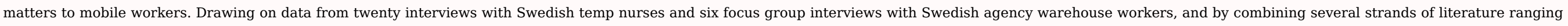

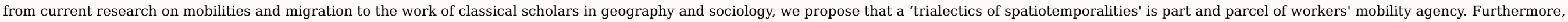

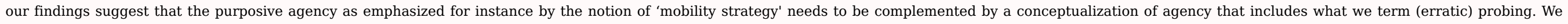
conclude that labour mobility may be strategic and a sign of power, but not always and everywhere, and not in any pure sense.

Keywords: Labour mobility; Agency; Spatiotemporalities; Migrant worker; Norway; Sweden

\section{Introduction}

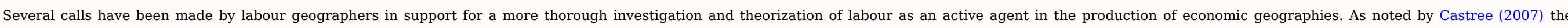

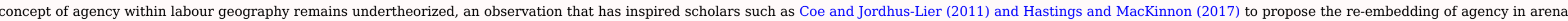

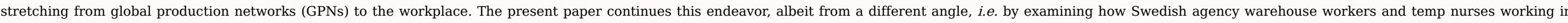

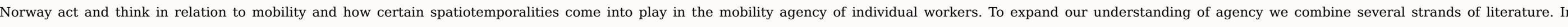

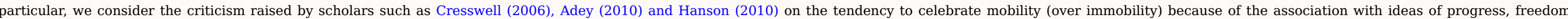

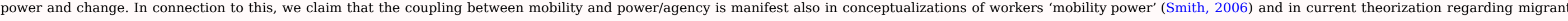
and immigrant workers' ability to strategize around their mobility (Hagan et al., 2011; Iskander et al., 2013; Alberti, 2014). 


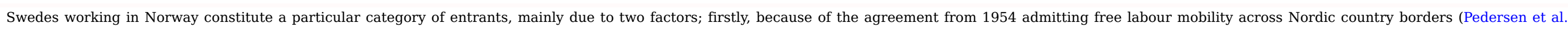

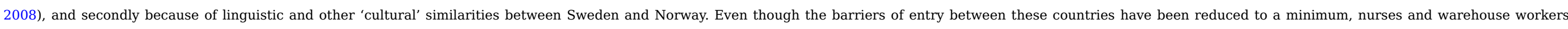

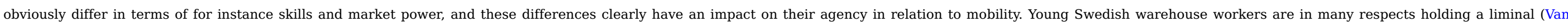

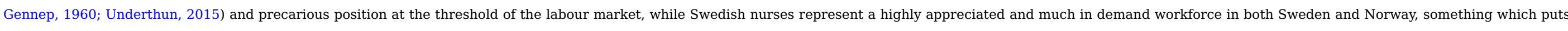

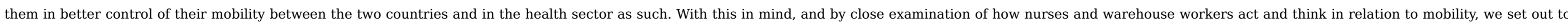

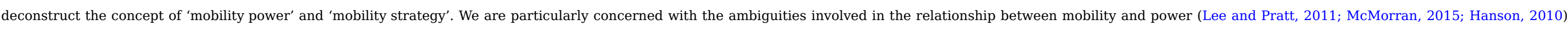

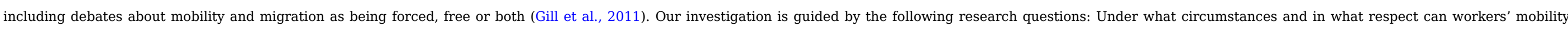

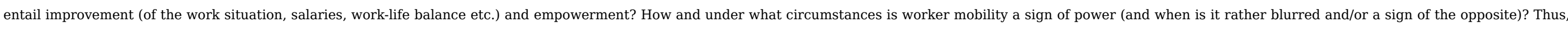

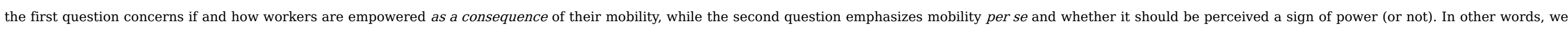
make an analytical distinction between 'empowerment by mobility' and 'mobility as power.'

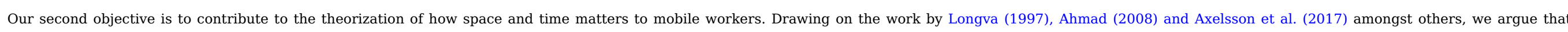

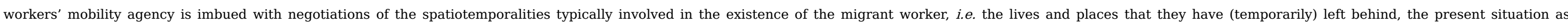

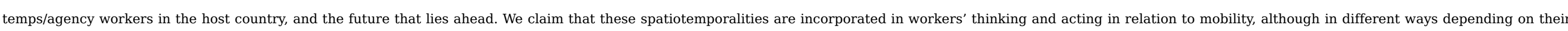

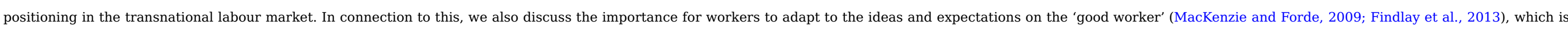
key to pursue one's mobility but which is equally important if one seeks 'a place to stay' (hence immobility).

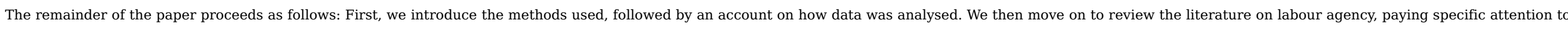

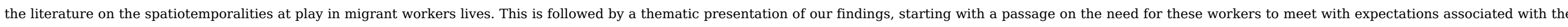

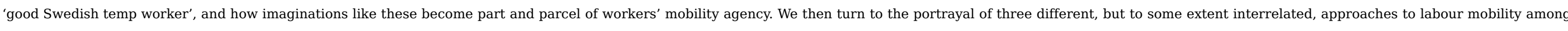

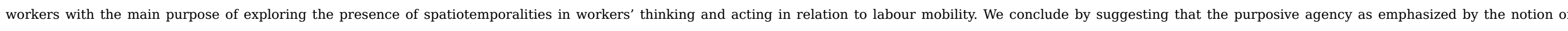

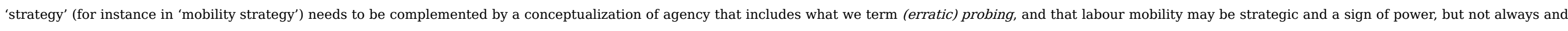
everywhere, and not in any pure sense.

\section{Methods and material}

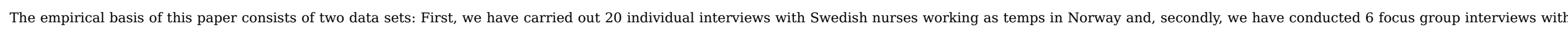

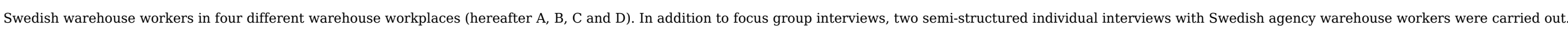
The differences in terms of methodology resulted from how the research project was set up, with two separate research teams operating with different methods while collecting the data.

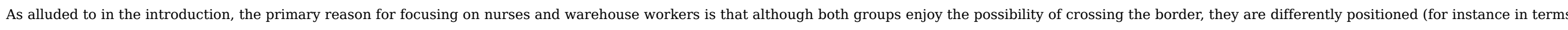
of skill levels) in the labour market, and as such they make up for interesting cases to compare.

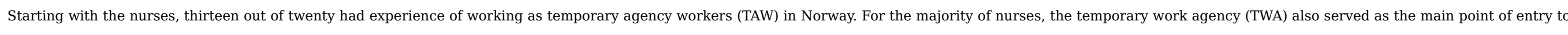

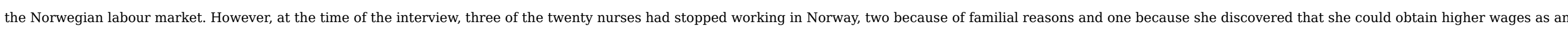

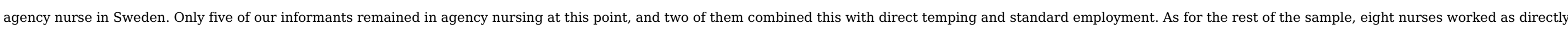
employed temp nurses at the time of the interview, and four had obtained a standard employment contract (three in Sweden and one in Norway)

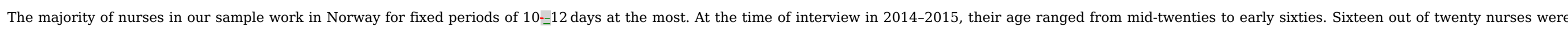

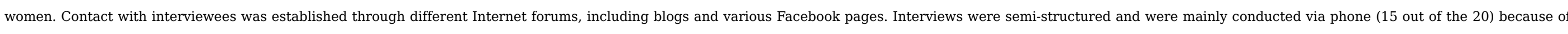

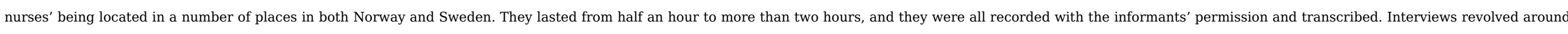

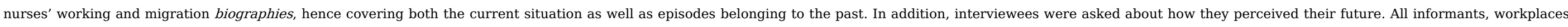




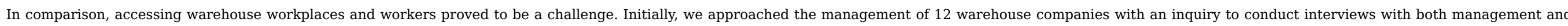

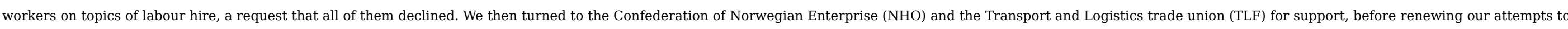

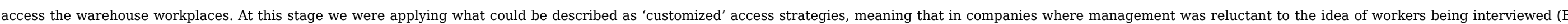

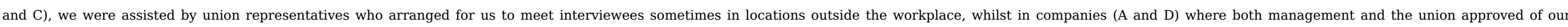

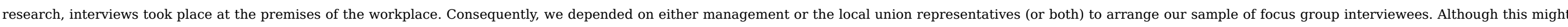

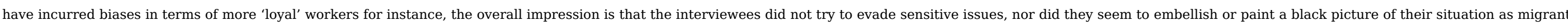

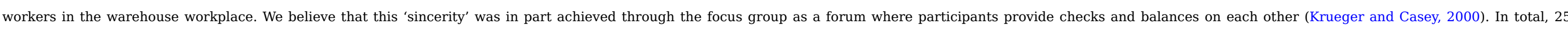

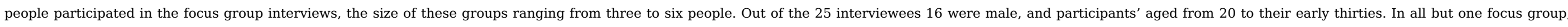

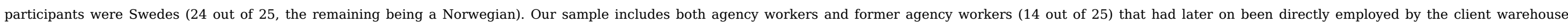
companies on regular contracts.

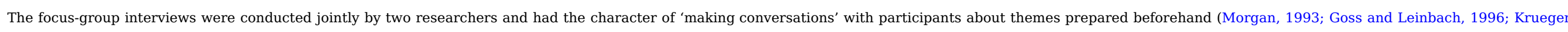

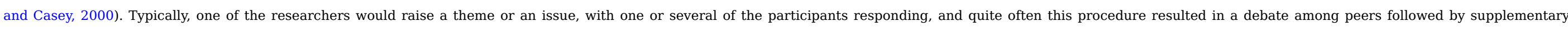

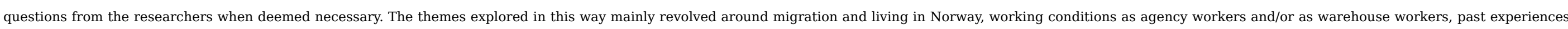
and future prospects. Interviews lasted for one to two hours, they were recorded with the informants' permission and transcribed verbatim. All informants and workplaces have been anonymized.

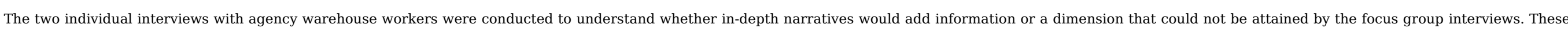

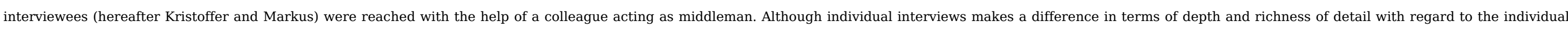

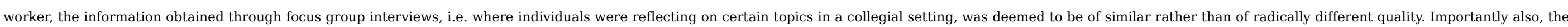
data acquired through focus group interviews was considered sufficient to answer to the overall research questions of the project.

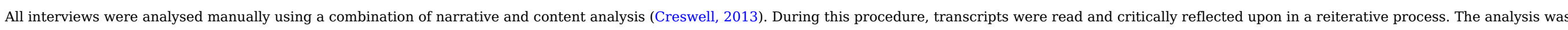

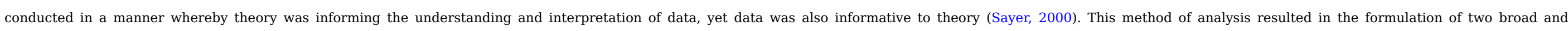

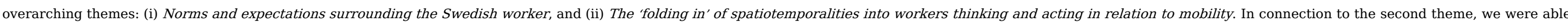

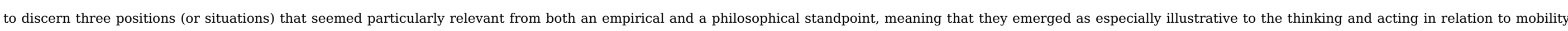

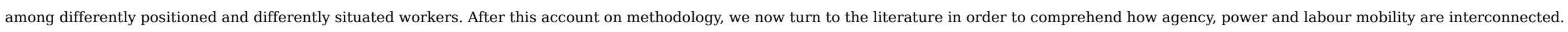

\section{Agency in labour geography, labour (im)mobilities and power}

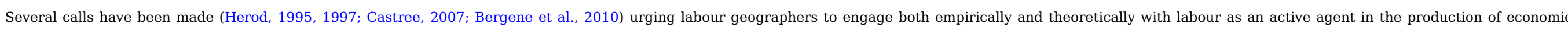

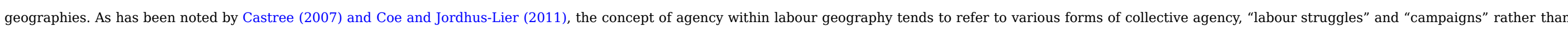

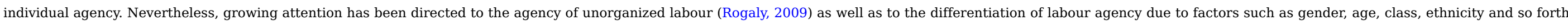

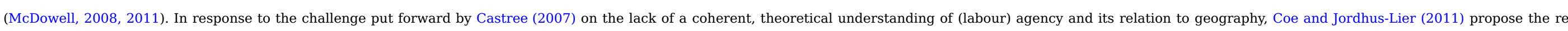

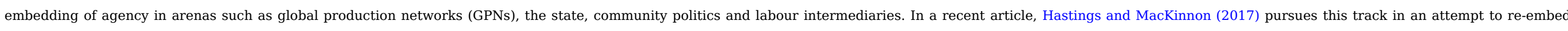

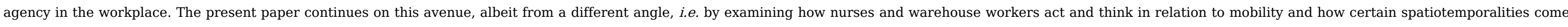
into play in the mobility agency of individual workers.

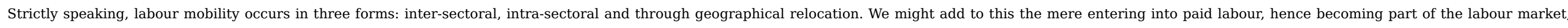

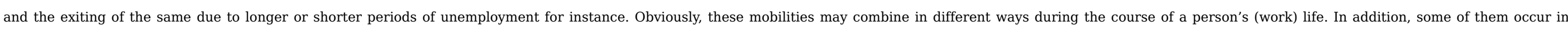
accordance with certain temporalities, for instance due to fluctuating demand patterns. That said, let us now turn to the thorny issue of mobility and power. 


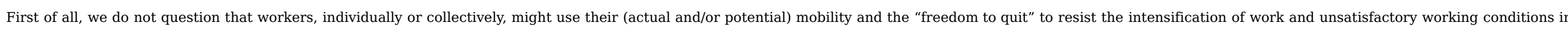

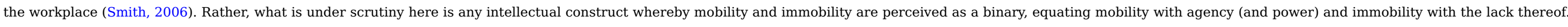

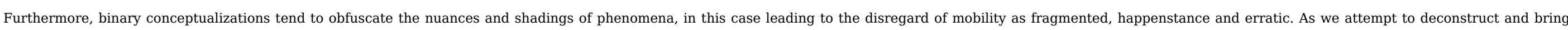

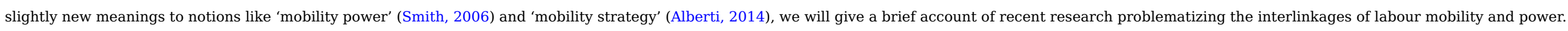

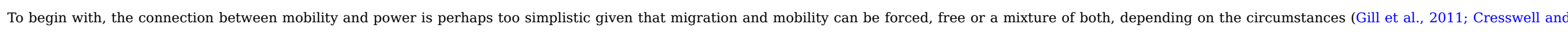

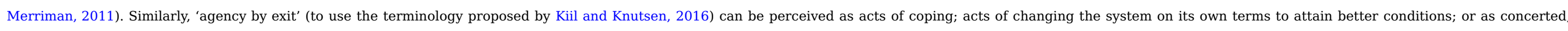
planned and voiced efforts to change power relations and attain sustainable improvements. The outcomes will however vary with context and the sources of power the workers are able to draw on.

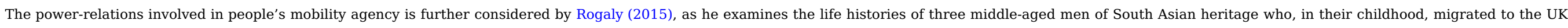

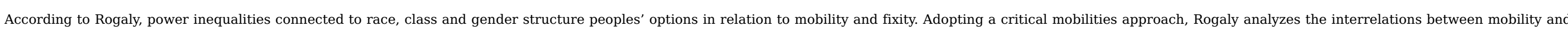

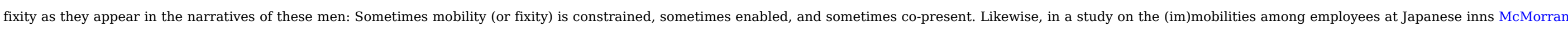

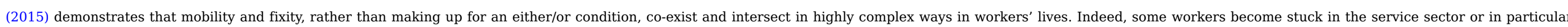

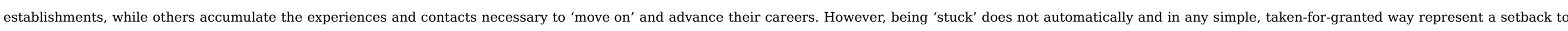

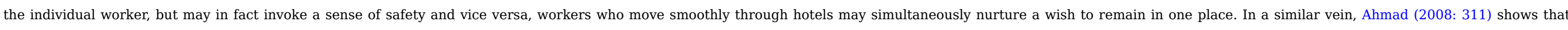

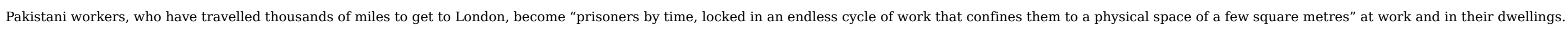

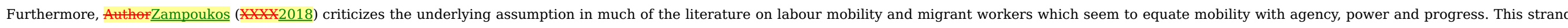

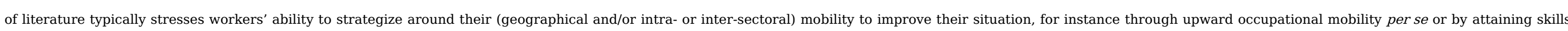

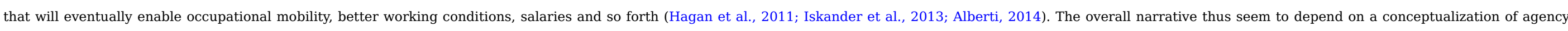

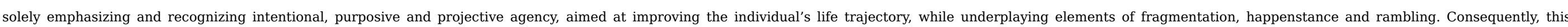
portrayal implies a figure knowledgeable and in control of his/her options and, we might add, whom is therefore able to manage his/her future.

\section{Agency, space and time - old questions anew}

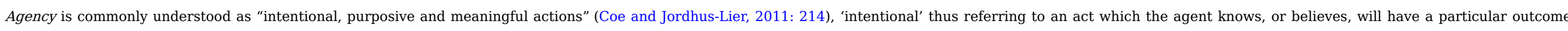

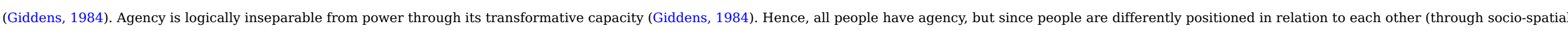

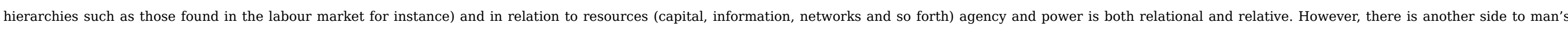

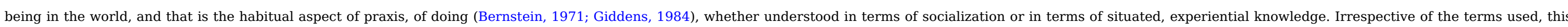
points to agency as having an inherent temporal dimension. For instance, sociologists Emirbayer and Mische (1998: 963) set out to conceptualize human agency as:

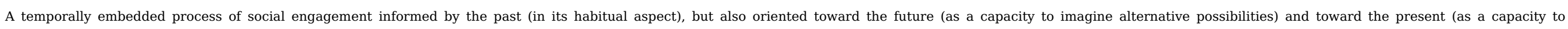
contextualize past habits and future projects within the contingencies of the moment).

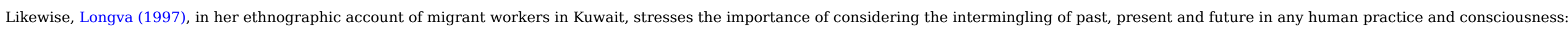

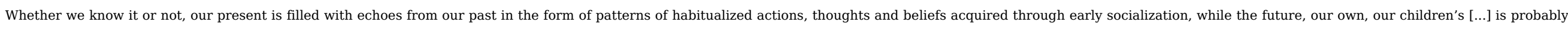

what we really live for. [...] Also, the interpretation of the past as well as the perception of the present are to a large extent colored by the hopes and fears we hold about the future that lies ahead of us (Longva, 1997: 175).

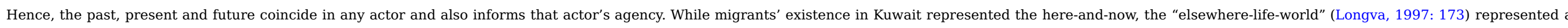

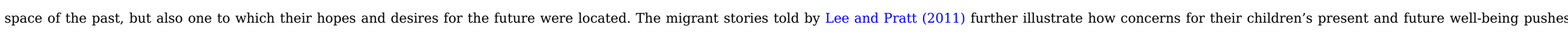

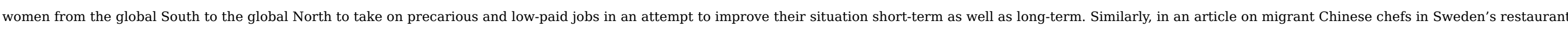

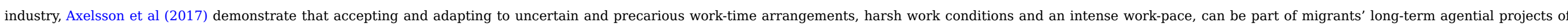




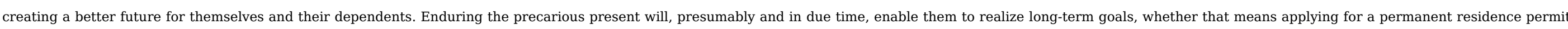
and accessing full labour market rights, or mainly saving money to build a future for themselves in China.

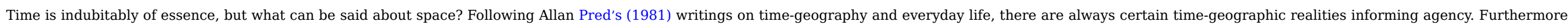
the biography of a person is "ever on the move with her" as:

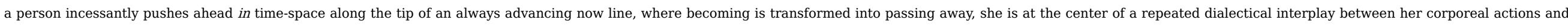

her mental activities and intentions, between what she physically does and what she is able to know and think (Pred, 1981:1, emphasis added).

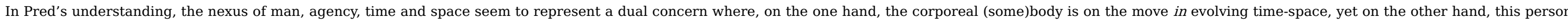

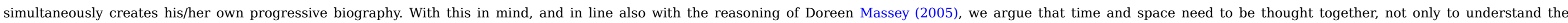

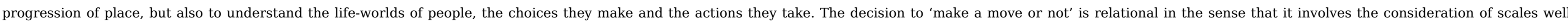

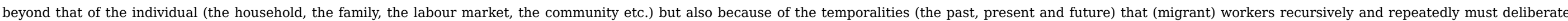

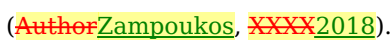

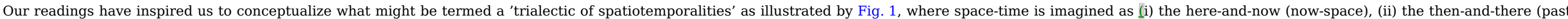
space), and (iii) as an imagined, future space (may-be-space), which may or may not come into realization (Hägerstrand, 1996; Lefebvre, 1991; Longva, 1997).

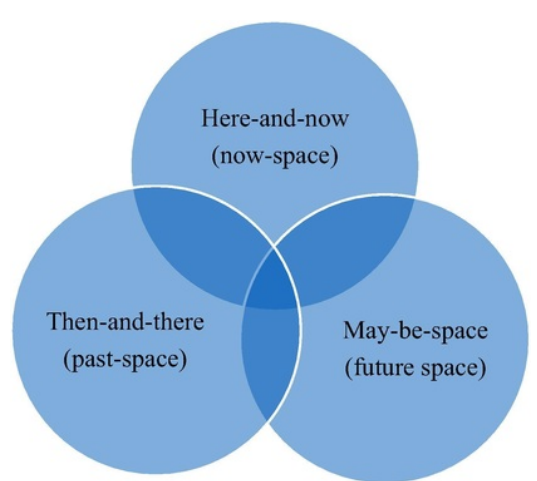

Fig. 1 The trialectics of spatiotemporalities incorporated in the mobility agency of workers.

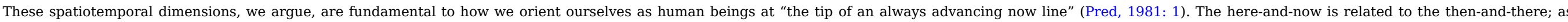

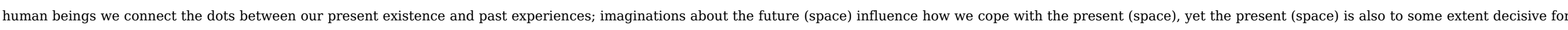

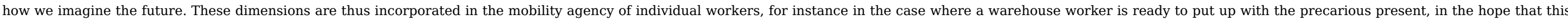
will transcend into a stable and secure future, or when a Swedish nurse decides to leave deteriorating work conditions in Sweden and opts for a better future as a temp nurse in Norway.

\section{Being a 'good' Swedish temp (agency) worker}

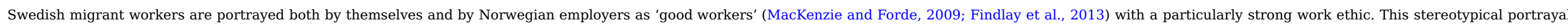

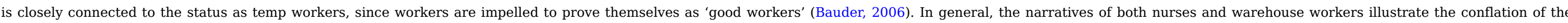

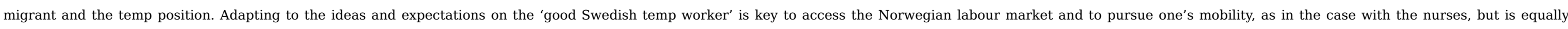
important if one seeks 'a place to stay' (hence immobility) as in the case of some of the 'older' warehouse workers.

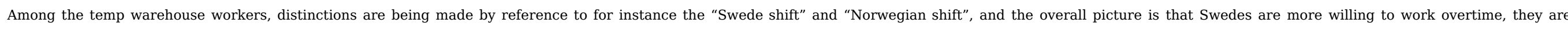

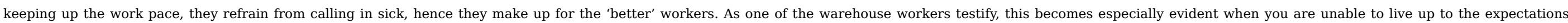




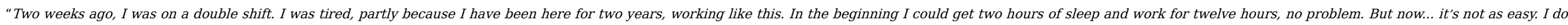

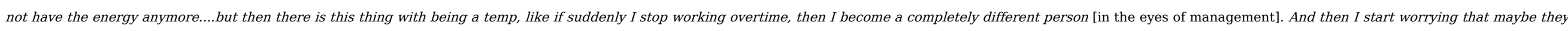

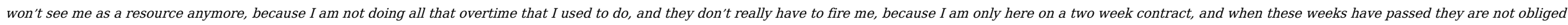
to tell me why my contract is not renewed" (Focus group interview, Company D).

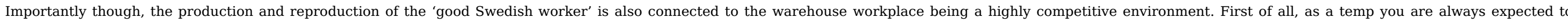

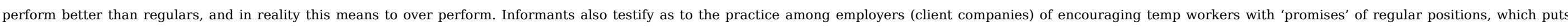

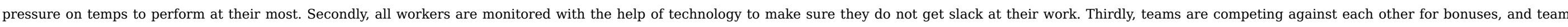

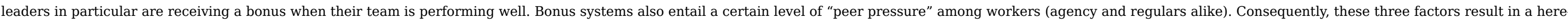

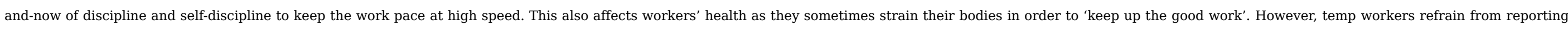
sick because again this does not comply with the idea of the 'good' Swedish worker, nor will it improve one's chances of getting a permanent position

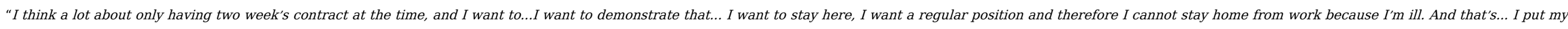
health on risk, only because I wish to have a regular position" (Focus group interview, Company D).

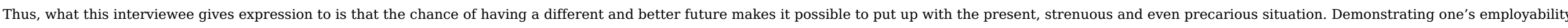
is perceived as the ticket to security and stability among warehouse workers whose intention is to stay on.

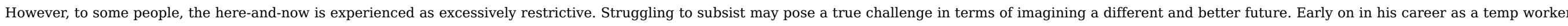

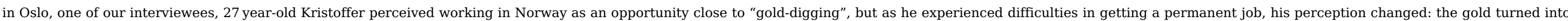
sand. When asked about his future, this was his response

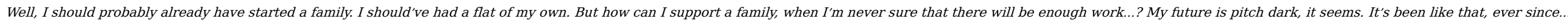

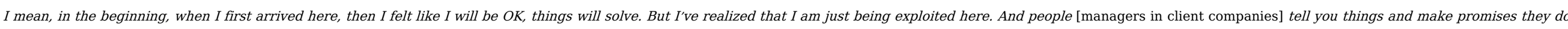
not intend to keep, just to make you show up at work the next day" (Interview, December 2014).

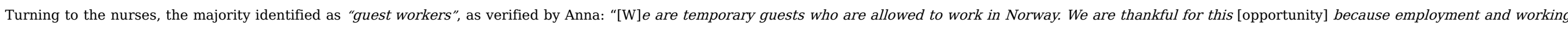
conditions are better [than in Sweden]".

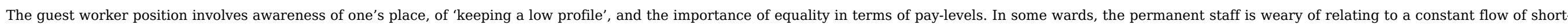

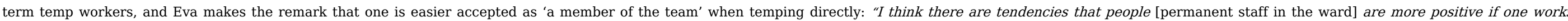

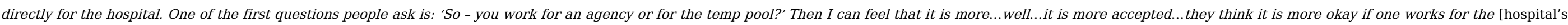

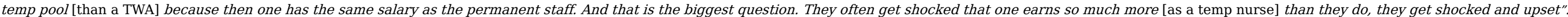

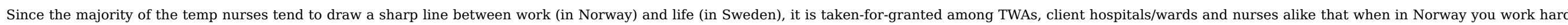

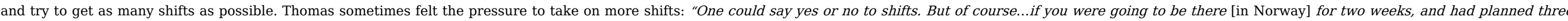

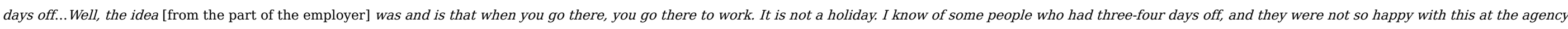
They never forced anyone, but of course they [the TWA] pay for accommodation, travel and everything, so they expect that you at least work full time".

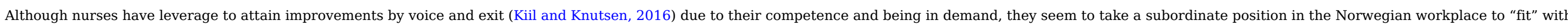

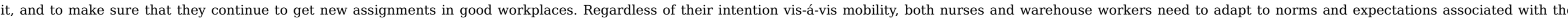

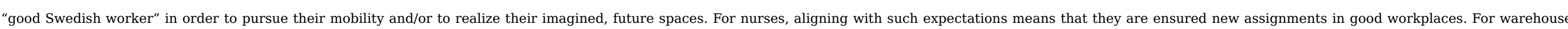


In the following we will take a closer look at nurses and warehouse workers agency in relation to mobility, in an attempt to further disentangle the relationship between mobility, agency and power

\section{Temping to do a good job and get well paid for it}

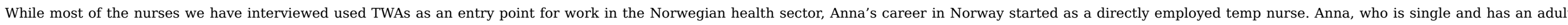

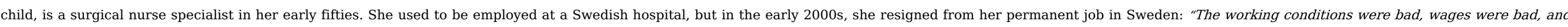

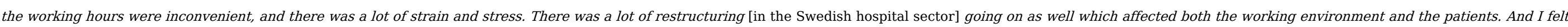
that...I didn't want to contribute to that. I felt that I wanted to get a job somewhere else where I could do what I am good at and get paid well for it".

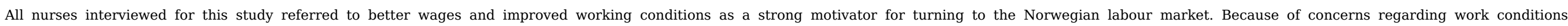

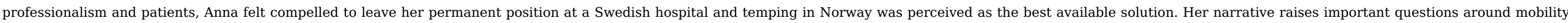

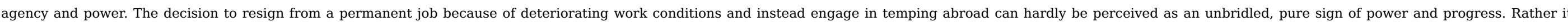
points to agency as being at once an expression of power and adaptation.

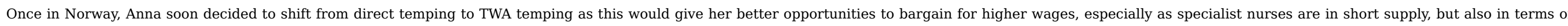

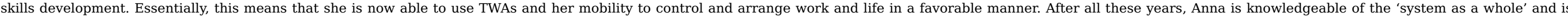

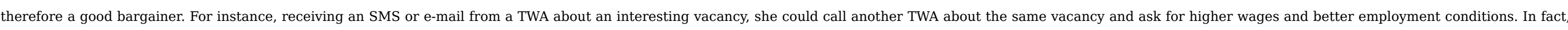

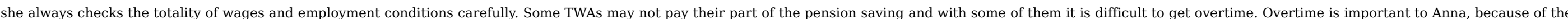
premium paid.

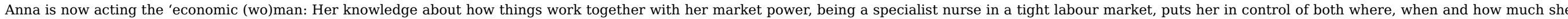

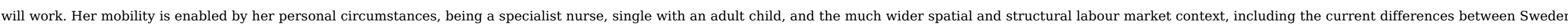

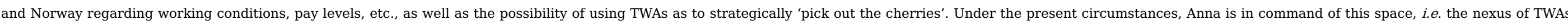

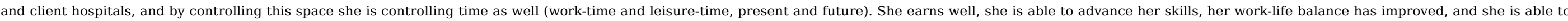

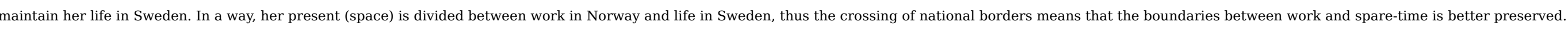

\section{Temping to travel - travel to temping}

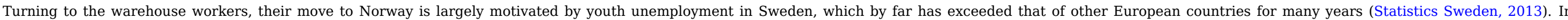

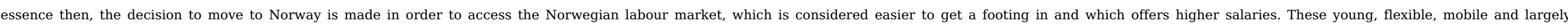

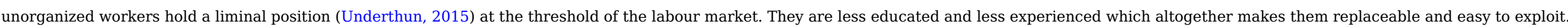

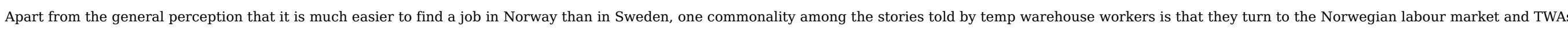

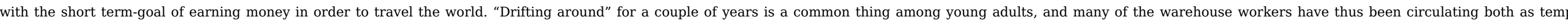

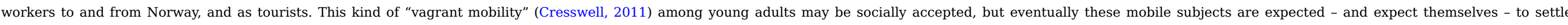
permanently. However, this may be easier said than done, as will be demonstrated.

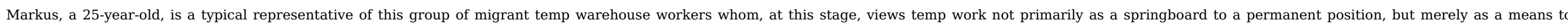

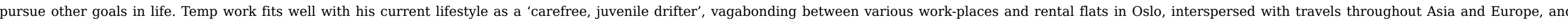
shorter periods back at his parents' home in Sweden.

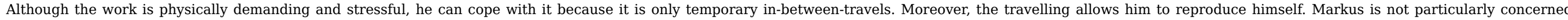

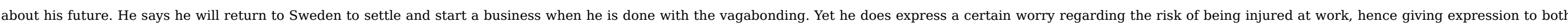




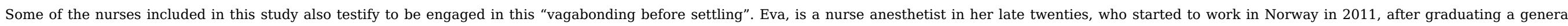

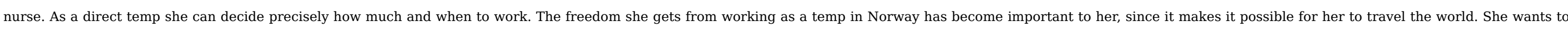

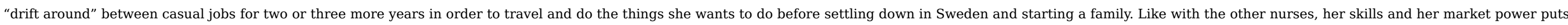

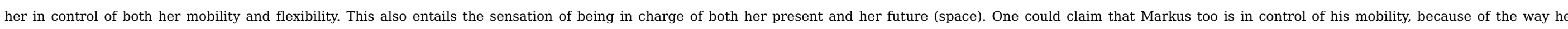

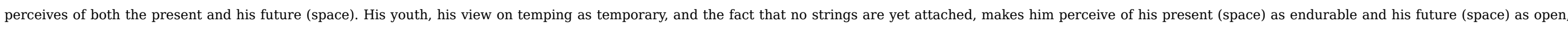
undefined and largely hopeful.

\section{Lost in transition?}

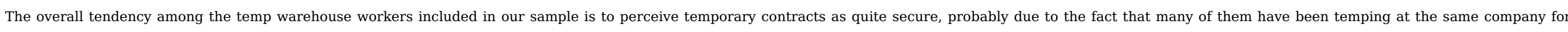
several years. At the same time however, they are painfully aware of the restrictions that temp work means to their short-term as well as long-term existence.

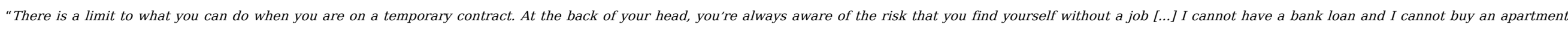

because I have no regular position with a steady income [...]. (Focus group interview, Company D).

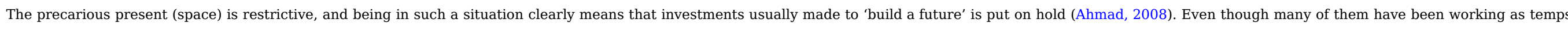

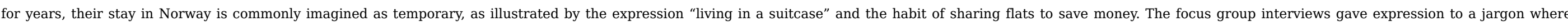

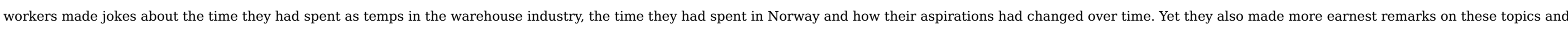

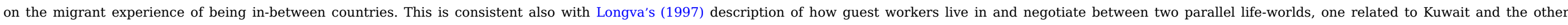
'elsewhere', usually denoting migrants' home countries.

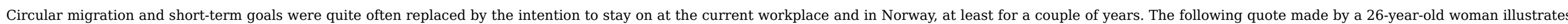
this:

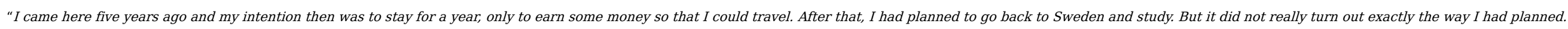

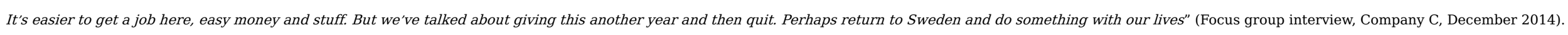

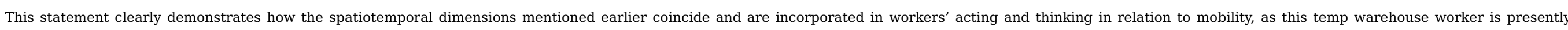

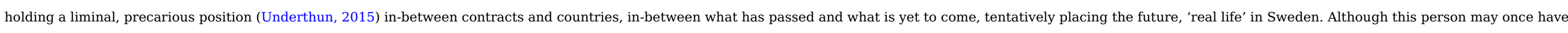

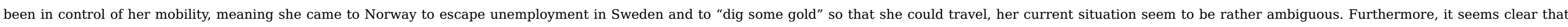

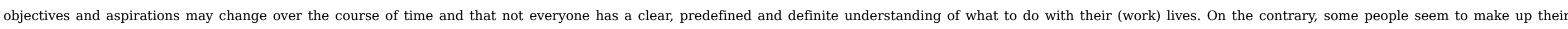
pathways as they go, which is why we need to scrutinize notions like 'mobility power' and 'mobility strategy'.

\section{Concluding discussion}

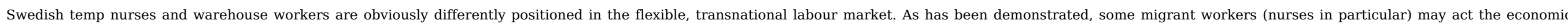

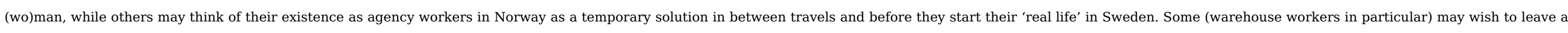

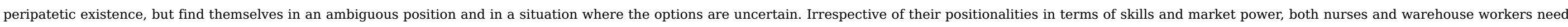
to prove themselves employable, "good workers" (MacKenzie and Forde, 2009; Findlay et al., 2013) in order to pursue their objectives, dreams and aspirations.

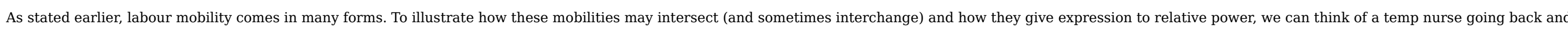

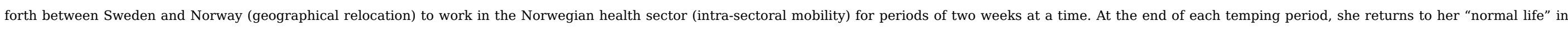

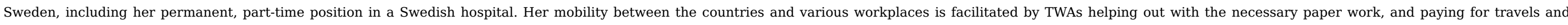




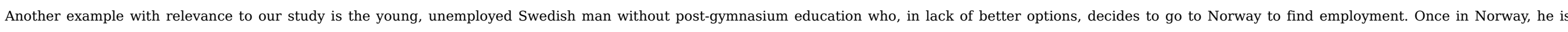

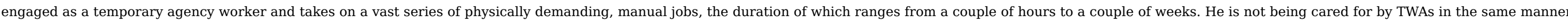

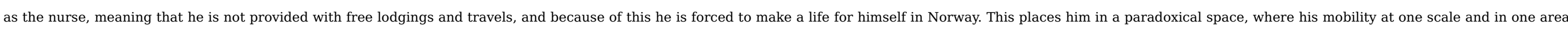

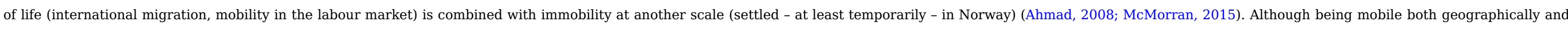

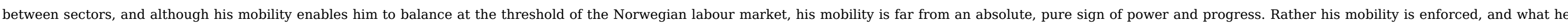

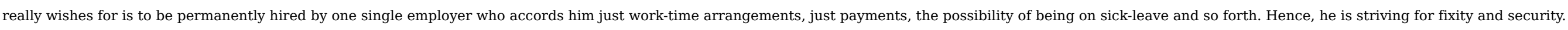

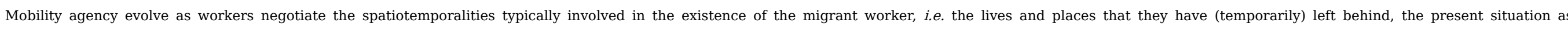

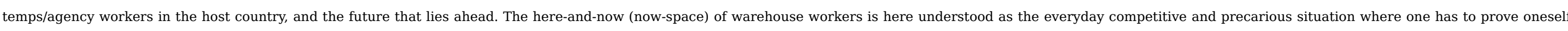

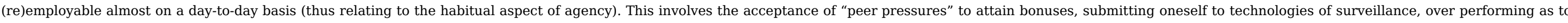

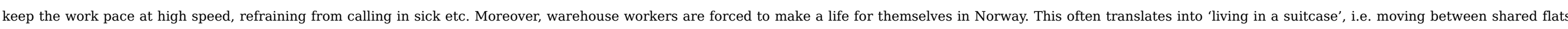

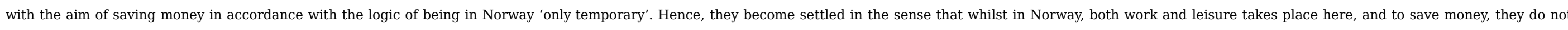

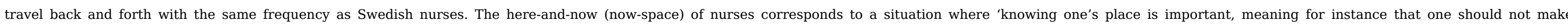

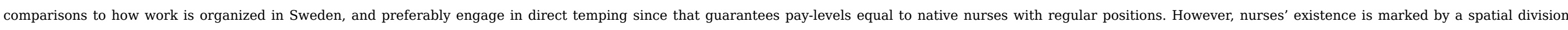
between work in Norway and life in Sweden.

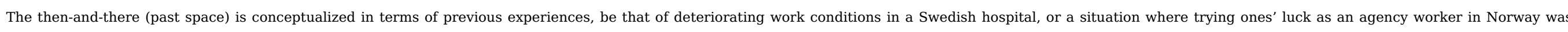

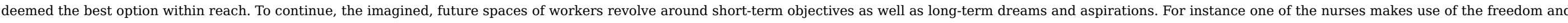

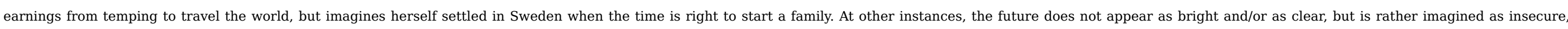
unforeseeable and tentative. This applies to agency warehouse workers in particular.

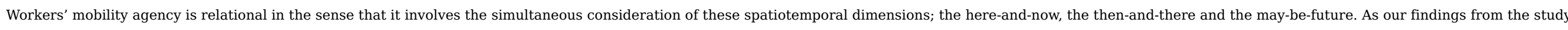

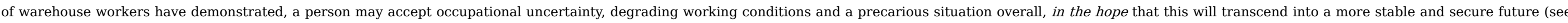

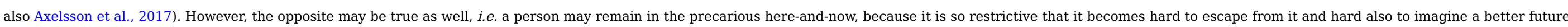

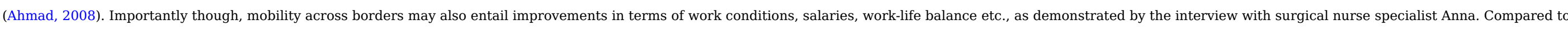
warehouse workers, nurses are better equipped to control both their present and to some extent their future space just by being in demand and by spatially dividing work in Norway and life in Sweden.

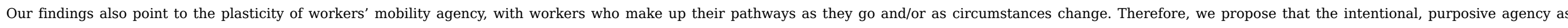

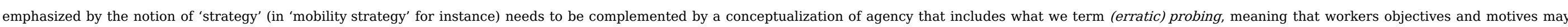

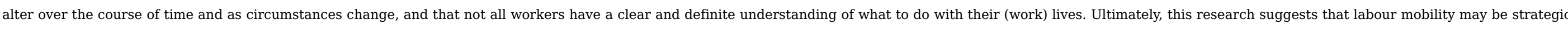

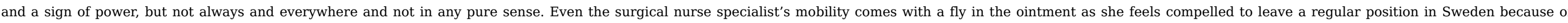

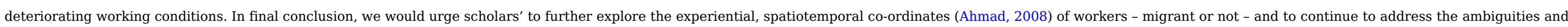
complexities involved in the mobility-power relationship.

\section{References}

Adey P., Mobility, 2010, Routledge; London and New York.

Ahmad A.N., Dead men working: time and space in London's (illegal') migrant economy, Work Employ. Soc. 22 (2), 2008, 301-318.

Alberti G., Mobility strategies, 'mobility differentials' and 'transnational exit': the experiences of precarious migrants in London's hospitality jobs, Work Employ. Soc. 28 (6), $2014,865-881$. 


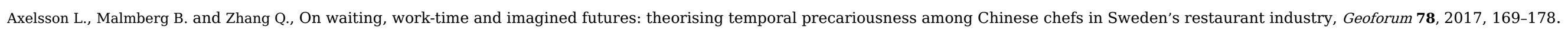
Bauder H., Labour Movement: How Migration Regulates Labour Markets, 2006, Oxford University Press; Oxford.

Bergene A.C., Endresen S.B. and Knutsen H.M., (Eds.), Missing Links in Labour Geography, 2010, Ashgate Publishing Ltd.

Bernstein R.J., Praxis and Action: Contemporary Philosophies of Human Activity, 1971, University of Pennsylvania Press.

Castree N., Labour geography: a work in progress, Int. J. Urban Reg. Res. 31 (4), 2007, 853-862.

Coe N. and Jordhus-Lier D., Constrained agency? Re-evaluating the geographies of labour, Prog. Hum. Geogr. 35 (2), 2011, 211-233.

Coe N. and Jordhus-Lier D., Re-embedding the agency of labour, In: Bergene A.-.C., (Ed), Missing Links in Labour Geography, 2010, Ashgate; Surrey.

Cresswell T., On the Move: Mobility in the Modern Western World, 2006, Taylor \& Francis; London and New York.

Cresswell T. and Merriman P., (Eds.), Geographies of Mobilities: Practices, Spaces, Subjects, 2011, Ashgate Publishing Ltd.

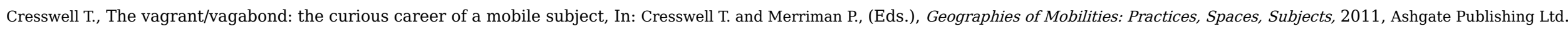

Creswell J.W., Qualitative Inquiry and Research Design: Choosing among Five Approaches, 2013, Sage; Thousand Oaks, CA.

Emirbayer M. and Mische A., What is agency?, Am. J. Sociol. 103 (4), 1998, 962-1023.

Findlay A., McCollum D., Shubin S., Apsite E. and Krisjane Z., The role of recruitment agencies in imagining and producing the 'good' migrant, Soc. Cult. Geogr. 14 (2), 2013 , 145-167.

Giddens A., The Constitution of Society, 1984, Polity Press; Cambridge.

Gill N., Caletrio J. and Mason V., Introduction: mobilities and forced migration, Mobilities 6, 2011, 301-316.

Goss J.D. and Leinbach T.R., Focus groups as alternative research practice: experience with transmigrants in Indonesia, Area 1996, 115-123.

Hagan J., Lowe N. and Quingla C., Skills on the move: rethinking the relationship between human capital and immigrant economic mobility, Work Occup. 38 (2), 2011 , $149-178$.

Hanson S., Gender and mobility: new approaches for informing sustainability, Gend. Place Cult.: J. Feminist Geogr. 17 (1), $2010,5-23$.

Hastings T. and MacKinnon D., Re-embedding agency at the workplace scale: workers and labour control in Glasgow call centres, Environ. Plan. A 49 (1), 2017, 104-120.

Herod A., From a geography of labour to a labour geography: labour's spatial fix and the geography of capitalism, Antipode 29 (1), $1997,1-31$.

Herod A., The practice of international labour solidarity and the geography of the global economy, Econ. Geogr. 71 (4), 1995, 341-363.

Hägerstrand T., Diorama, path and project, In: Agnew J., Livingstone D.N. and Rogers A., (Eds.), Human Geography - An Essential Anthology, 1996, Blackwell Publishing Ltd; USA, Malden, 650-674.

Iskander N., Riordan C. and Lowe N., Learning in place: immigrants spatial and temporal strategies for occupational advancement, Econ. Geogr. 89 (1), 2013 , 53-75.

Kiil M.B. and Knutsen H.M., Agency by exit: Swedish nurses and the “Not below 24 000" movement, Geoforum 70, 2016, 105-114.

Krueger R.A. and Casey M.A., Focus Groups: A Practical Guide for Applied Research, third ed., 2000, Sage; Thousand Oaks, CA.

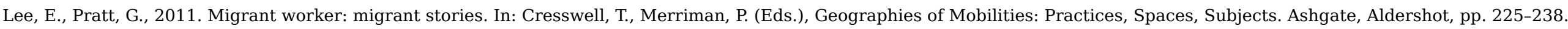
Lefebvre H., The Production of Space, 1991, Blackwell Publishers.

Longva A.N., Walls Built on Sand: Migration. Exclusion, and Society in Kuwait, 1997, Westview Press; Boulder, CO. 
MacKenzie R. and Forde C., The rhetoric of the good worker 'versus the realities of employers' use and the experiences of migrant workers, Work Employ. Soc. 23 (1), 2009, 142-159.

Massey D., For Space, 2005, Sage Publications; London, Thousand Oaks and New Delhi.

McDowell L., Working Bodies: Interactive Service Employment and Workplace Identities vol. 61, 2011, John Wiley \& Sons.

McDowell L., Thinking through work: complex inequalities, constructions of difference and trans-national migrants, Prog. Hum. Geogr. 32 (4), $2008,491-507$.

McMorran C., Mobilities amid the production of fixities: labour in a Japanese Inn, Mobilities 10 (1), 2015, 83-99.

Morgan D.L., (Ed), Successful Focus Groups: Advancing the State of the Art vol. 156, 1993, Sage Publications.

Pedersen, P.J., Røed, M., Wadensjö, E., 2008. The Common Nordic Labour Market at 50. TemaNord 2008:506. Nordic Council of Ministers, Copenhagen.

Pred A., Social reproduction and the time-geography of everyday life, Geogr. Ann., Ser. B, Hum. Geogr. 63 (1), 1981, 5-22.

Rogaly B., Space and everyday life: labour geography and the agency of unorganized and temporary migrant workers, Geogr. Compass 4 (3), 2009, 1-13.

Rogaly B., Disrupting migration stories: reading life histories through the lens of mobility and fixity, Environ. Plan. D: Soc. Space 33 (3), 2015, 528-544.

Sayer A., Method in Social Science: A Realist Approach, second ed., 2000, Routledge; London.

Smith C., The double indeterminacy of labour power: labour effort and labour mobility, Work Employ Soc. 20 (2), 2006, 389-402.

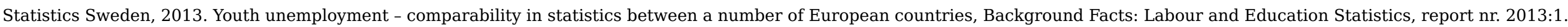

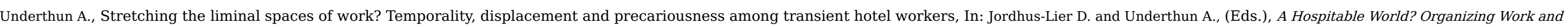
Workers in Hotels and Tourist Resorts, 2015, Routledge; London.

Van Gennep A., Rites of Passage, 1960, Chicago University Press; Chicago.

\section{Queries and Answers}

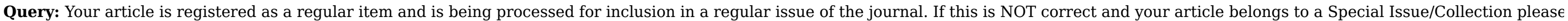
contact t.sankarappan@elsevier.com immediately prior to returning your corrections.

Answer: Yes

Query: The author names have been tagged as given names and surnames (surnames are highlighted in teal color). Please confirm if they have been identified correctly.

Answer: Yes

Query: Please check the insertion of abstract, and correct if necessary.

Answer: Everything seems fine with the abstract.

Query: Please check the keywords that the copyeditor has assigned, and correct if necessary.

Answer: Keywords fine.

Query: Please check the hierarchy of the section headings.

Answer: Section headings are fine.

Query: As per publisher's style, references citations have been edited throughout the text. Please check, and correct if necessary.

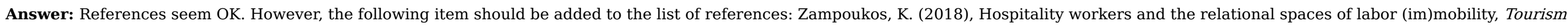


Geographies 20 (1), pp. 49-66.

Query: Please check and replace the appropriate citation for Author (XXXX).

Answer: Done. See also response to Q6. 